San Jose State University

SJSU ScholarWorks

Master's Theses

Master's Theses and Graduate Research

1992

\title{
The Prevalence of ergogenic aid use among female high school athletes in a Santa Clara Valley High School District
}

Mary M. Brkich

San Jose State University

Follow this and additional works at: https://scholarworks.sjsu.edu/etd_theses

\section{Recommended Citation}

Brkich, Mary M., "The Prevalence of ergogenic aid use among female high school athletes in a Santa Clara Valley High School District" (1992). Master's Theses. 376.

DOI: https://doi.org/10.31979/etd.vq8c-f328

https://scholarworks.sjsu.edu/etd_theses/376

This Thesis is brought to you for free and open access by the Master's Theses and Graduate Research at SJSU ScholarWorks. It has been accepted for inclusion in Master's Theses by an authorized administrator of SJSU ScholarWorks. For more information, please contact scholarworks@sjsu.edu. 


\section{INFORMATION TO USERS}

This manuscript has been reproduced from the microfilm master. UMI films the text directly from the original or copy submitted. Thus, some thesis and dissertation copies are in typewriter face, while others may be from any type of computer printer.

The quality of this reproduction is dependent upon the quality of the copy submitted. Broken or indistinct print, colored or poor quality illustrations and photographs, print bleedthrough, substandard margins, and improper alignment can adversely affect reproduction.

In the unlikely event that the author did not send UMI a complete manuscript and there are missing pages, these will be noted. Also, if unauthorized copyright material had to be removed, a note will indicate the deletion.

Oversize materials (e.g., maps, drawings, charts) are reproduced by sectioning the original, beginning at the upper left-hand corner and continuing from left to right in equal sections with small overlaps. Each original is also photographed in one exposure and is included in reduced form at the back of the book.

Photographs included in the original manuscript have been reproduced xerographically in this copy. Higher quality $6^{\prime \prime} \times 9$ " black and white photographic prints are available for any photographs or illustrations appearing in this copy for an additional charge. Contact UMI directly to order.

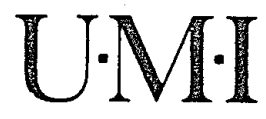

University Microfıms Internatıonal

A Bell \& Howell Intormation Company 

Order Number 1350070

The prevalence of ergogenic aid use among female high school athletes in a Santa Clara Valley high school district

Brkich, Mary M., M.A.

San Jose State University, 1992

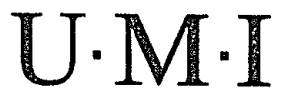



THE PREVALENCE OF ERGOGENIC AID USE AMONG FEMALE HIGH SCHOOL ATHLETES

IN A SANTA CLARA VALLEY HIGH SCHOOL DISTRICT

\author{
A Thesis \\ Presented to \\ The Faculty of the \\ Department of Human Performance \\ San Jose State University \\ In partial Fulfillment \\ of the Requirements for the Degree \\ Master of Arts
}

By

Mary M. Brkich

August, 1992 
Approved by the Department of Human Performance

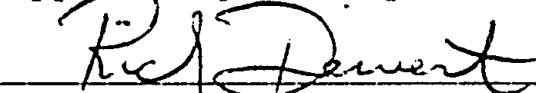

Dr. Rich Deivert

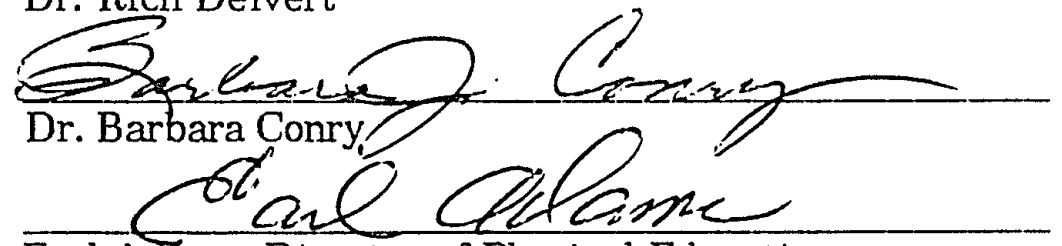

Earl Adams, Director of Physical Education

Campbell Union High School District

Approved by the University

In. Lou Lewandsoreh. 


\begin{abstract}
THE PREVALENCE OF ERGOGENIC AID USE AMONG FEMALE HIGH SCHOOL ATHLETES IN A SANTA CLARA VALLEY HIGH SCHOOL DISTRICT

by Mary M. Brkich
\end{abstract}

The purpose of this investigation was to determine the use of ergogenic aids among female high school athletes in a bay area high school district. Questionnaires were administered to 323 females participating in sports at six high schools within the Santa Clara Valley. Pain tablets and pain creams or lotions were the two most frequently cited substances, followed closely by caffeine and special diets, for the purpose of enhancing performance. No female athlete reported use of anabolic steroids, but amphetamine use was reported (5\%). The most common reasons for using an ergogenic aid were to treat or prevent an injury (38.5\%), and to decrease fat (24.6\%). Users reported that family members and doctors were their main sources of information, while non-users relied on the media for their information about ergogenic aids. The majority of subjects (83.3\%) thought it was unfair for substance users to compete in the same contest as nonusers and agreed that the effects of ergogenic aids were bad. Most of the subjects (71.8\%) want to participate in college athletics, over half of them (51.1\%) hoping for a scholarship. Users ranked their strength and overall health above the non-users. These findings indicated that more effective education and prevention programs are needed to curb the continued, frequent use of these substances by female, high school athletes. 


\section{Table of Contents}

Abstract

Table of contents

Chapter

1. Introduction

Title IX

Increased female sport participation

Female role models

Statement of purpose

Significance of the study

Delimitations

Limitations

Definition of terms

2. Review of literature

History of ergogenic aid use

$\begin{array}{lr}\text { Studies of ergogenic aid use } & 10\end{array}$

Summary

3. Procedures

Subjects

Development of the questionnaire $\quad 17$

$\begin{array}{ll}\text { Administration of the survey } & 19\end{array}$

$\begin{array}{ll}\text { Statistical procedures } & 190\end{array}$

$\begin{array}{ll}\text { Content validity and reliability } & 21\end{array}$

4. Results of the questionnaire

Demographics of the pilot study sample 23

Prevalence of ergogenic aid use in the pilot study sample 23

Factors related to performance-enhancing substance use among the pilot study sample

Future in athletics among the pilot study sample 24

Self-perception of the pilot study sample 24

Relationships and correlations of the pilot study 24

$\begin{array}{ll}\text { Demographics of the main sample } & 25\end{array}$

Prevalence of ergogenic aid use among the main sample 25

Factors related to performance-enhancing substance use among the main sample

Future in athletics among the main sample 32 
Table of contents (continued)

Self-perception of the main sample 32

Relationships and correltations of the main sample 32

5. Conclusion and discussion

Summary of procedures

Summary of findings $\quad 35$

Conclusions $\quad 37$

Discussion $\quad 39$

Recommendations for further study 41

Summary $\quad 42$

6. References 43

7. Appendix A-The questionnaire 47

8. Appendix B-Letter of confirmation-Principal 1

9. Appendix C-Letter of confirmation-Principal 2

10. Appendix D-Letter of confirmation-Principal 3

11. Appendix E-Letter of confirmation-Principal 4

12. Appendix F-Letter of confirmation-Principal 5

13. Appendix G-Letter of confirmation-Athletic Director 1

14. Appendix H-Letter of confirmation-Athletic Director $2 \quad 56$

15. Appendix I-Letter of confirmation-Athletic Director 3

16. Appendix J-Letter of confirmation-District Director of PE 58

17. Appendix K-Consent form 59

18. Appendix L-Statement read to subjects 61 


\section{LIST OF TABLES}

page

Table 1 Self-reported participation by sport 26

Table 2 Ergogenic substances identified as being used by another female $\quad 26$

Table 3 Self-reported personal use of ergogenic aids 27

Table 4 Self-reported ergogenic aid use by sport 29

Table 5 Self-reported sources of information about performanceenhancing substances

31

Table 6 Self-reported perception of health 33

Table 7 Self-reported perception of strength 33 


\section{ACKNOWLEDGEMENTS}

I would like to thank my committee members, Dr. Rich Deivert, Dr. Barbara Conry, and Earl Adams .

In addition, I extend special thanks to Dr. Bethany Shifflet for her guidance, advice, and insight on the statistical design of this investigation.

Gratitude is also extended to the high school district and its faculty of the physical education department, for their full cooperation and interest in the welfare of their student athletes.

Furthermore, I am especially grateful to my roommates and friends for their encouragement, sense of humor, and frequent kind words.

And finally, all my love to my parents, who have always supported me, encouraged me to do my best, and reminded me that with God, all things are possible. 


\section{Chapter 1}

Introduction

According to Krochuk (1989), ergogenic aids are substances thought to improve sports performance, the most common categories of which include anabolic steroids, stimulants, analgesics, and nutritional supplements. A number of researchers have investigated the prevalence of anabolic steroid use in adolescents (Buckley, 1988; Hallagan, 1989; Johnson, 1989; Krochuk, 1989; Terney \& McClain, 1990; Windsor, 1989; Yesalis, 1989). Only two studies address the prevalence of other ergogenic aids as a group (Krochuk, 1989; Percy, 1977); none of the above studies were specific to female adolescent athletes.

There are three specific areas relative to the increased use of ergogenic aids among female athletes that will be discussed in this chapter: 1) the passage of Title IX, 2) the increased participation of females in sport due to the passage of Title IX, and 3) the greater number of athletic role models for women.

\section{Title IX}

Title IX is a law passed by the United States Congress in 1972 that "mandated equality of opportunity for females in all areas of school, including athletics" (Harris, 1987, p.99). Along with its passage came increased opportunities for women to participate in competitive athletics (for instance, the addition of female athletic teams on campuses, opportunities to play on male teams, new or improved equipment, and increased budgets). Opportunities also exist in the form of additional 
athletic scholarships, and types of sport-oriented careers (NSCA, 1989). As a result, female athletes are making the same commitment to training as men. There is also greater emphasis on winning. In addition, pressure to please coaches in the form of perfect scores, weight loss or maintenance, higher level of skill development, and more vigorous training schedules, and win-at-all-cost traps exist (Duda, 1986). All of these pressures may lead to chemical use to enhance performance. Women want to prove that they can perform well and pursue excellence in sport (Haycock, 1980), despite supposed physical and emotional vulnerabilities. This attitude has produced a breed of athlete with little fear of swallowing or being injected with almost anything that promises athletic success (Haycock,1980).

\section{Increased Female Sports Participation}

After the passage of Title IX, the number of female participants in sport grew astronomically. Participation in high school sports increased by $600 \%$ (Harris, 1987). Further evidence of this increase is discussed by Hogan (1977):

A survey by the National Federation of High School Associations reports that in the 1970-1971 school year, 3,666,000 boys and 284,000 girls played sports on an interscholastic level. Only $7 \%$ of all students participating in high school sports were girls. During the 1976-1977 school year, 1,645,000 girls played interscholastic sports--29\% of the 5,754,000 total (p.421). In the 1983-1984 school year, the total number of female participants had increased to 1.8 million (Duda, 1986). 
One consequence of this increased participation is a better quality athlete. More females are putting in long hours for conditioning and training. "The new breed of female athlete is there to maximize her potential and to be successful; she is not there for social interaction and fun alone" (Harris, 1987, p.99).

Overall, changes in the sports world from the mid-1970s to mid 1980s have been dramatic for females. A wider variety of sport activities are available to adolescent females. Women are encouraged to be physically active, and opportunities provided for her in sport organizations have multiplied tremendously (Haycock, 1980).

\section{Female Role Models}

Today, more females are being recognized and rewarded for their athletic achievements. Duda (1986) states that television, newspapers, magazines and charitable organizations have all contributed to this effort. The 1970s and 1980s have introduced great talents like Mary Lou Retton (gymnastics), Chris Evert (tennis), Florence Griffith-Joyner (heptathalon), and Nancy Lopez (golf). The 1990's explosion into sports has brought us the talents of Monica Seles (tennis), Kristi Yamaguchi (figure-skating), Jackie Joyner-Kersey (heptathalon), Bonnie Blair (speed skating), Maria Trujillo (marathon), and Jennifer Capriani (tennis). These women athletes mentioned above have made great strides in battling the contradiction of females taking on male characteristics to excel in female sports (Duda,1986). These new talents all maintain a wholesome, feminine image while exhibiting competitive excellence (Duda, 1986). These women 
athletes have shown the world that females can make a significant contribution to sport through their physical prowess without diminishing their femininity.

Since the passage of Title IX, female participation in sports has increased. A greater number of successful role models have emerged, and more adolescent females are becoming competitive athletes. These athletes are trying to maximize their potential as athletes. This may in turn explain the vulnerability of females to substance abuse, and stimulates further investigation of ergogenic aid use among female athletes at all levels.

\section{Statement of purpose}

The purpose of this study was to determine the use of ergogenic aids among female high school athletes. General attitudes about ergogenic substances were also investigated to determine if there was any relationship between use of ergogenic aids and how other variables dealing with belief systems were answered.

\section{Significance of the Study}

Many studies have documented the use of ergogenic aids (Buckley, 1988; Corder, 1975; Corley, 1990; Duda, 1986; Dymant, 1987; Fuller, 1987; Hallagan, 1989; Johnson, 1989; Krochuk, 1989; Newman, 1986; Terney, 1990; Windsor, 1989; Yesalis, 1989). These studies however, have dealt with a particular ergogenic aid, male high school athletes only, and/or a general high school population. 
The present study was significant because it concentrated on female high school athletes specifically, and several ergogenic aids. This has not been accomplished in any previous study.

\section{Delimitations}

This study was delimited as follows:

1. Only female high school athletes were investigated.

2. Six high schools in the Santa Clara Valley were selected to participate in the study.

3. Selected ergogenic aids were investigated. These ergogenic aids, respectively, were: amphetamines, anabolic steroids, analgesics, caffeine, diuretics, laxatives, electrolyte drinks, protein or amino acid supplements, special diets, and vitamin or mineral supplements.

4. Sports included in the study were: basketball, badminton, cross country, field hockey, softball, soccer, swimming, tennis, track, and volleyball.

\section{Limitations}

This study was limited by:

1. The mode of collection of data, namely, a self-report questionnaire.

2. Each subject was surveyed only once despite the fact that they participated in more than one sport; therefore, sports-specific information was unattainable. 
3. The number of subjects available to survey was affected by attendance on the particular day or during the particular period during which the survey took place.

4. The accuracy of results was dependent upon honesty in the athletes' reports.

\section{Definition of Terms}

To understand and interpret most clearly the findings of this study, one must be familiar with the terminology used. For the sake of clarity, and brevity, the following terms are defined:

Amino acid supplement: An increase in dietary amino acid intake, usually via amino acid tablets, powders, or liquids (Williams, 1974).

Amphetamine: Central nervous system stimulant which produces mood elevation with increased wakefulness, alertness, concentration, and physical performance. Systolic and diastolic blood pressures are raised, the respiratory center is stimulated, and appetite is suppressed through a central effect (Merck, 1987).

Anabolic steroid: Chemical compound similar to testosterone that stimulates anabolism--the building of muscle tissue through nitrogen retention (Williams, 1974, Taber, 1985).

Analgesic: Pain reliever, anaesthetic agent, used without loss of consciousness (Williams, 1974).

Athlete: A female who participates in an interscholastic sport during the 1990-1991 academic year. 
Diet: Liquid and solid food substances regularly consumed that reduces the caloric content sufficiently to cause weight loss (Taber, 1985).

Caffeine: Central nervous system stimulant derived from coffee, tea, and other common plants (Williams, 1974).

Diuretic: Agent used to increase secretion of urine (Williams, 1974).

Electrolyte drink: A liquid comprised of water, sugar, and selected vitamins and minerals ingested to prevent dehydration and to replace electrolyte loss from sweating (Webster, 1977).

Ergogenic aid: Agents which are utilized in attempts to increase work capacity (Williams, 1974).

Laxative: A food or chemical substance that acts to loosen the bowels (Taber, 1985).

Protein supplement: Increase in dietary protein, usually via high content protein tablets or powders (Williams, 1974).

Stimulant: Any agent temporarily increasing functional activity. Stimulants may be classified according to the organ upon which they act (Taber, 1985).

Supplement: A preparation (such as a pill, powder, or liquid) containing nutrients (Hamilton, 1988).

Vitamin or mineral supplement: Increase in dietary vitamin or mineral intake via tablets or special drinks (Williams, 1974). 
Chapter 2

Review of Literature

Research regarding ergogenic aid use among female high school athletes has been negligible, mainly because the emergence of the female athlete is a relatively new phenomenon in the world of sport. However, because of pressures for women's programs to grow and produce quickly, many changes in women's sports have occurred recently. One change that has occurred was the introduction of Title IX. "Equal opportunity" means more than merely providing teams and sporting events for females. "It means providing experiences that increase self-confidence and that result in improved self-expectations, greater probability of involvement, greater persistence in activity, and greater likelihood of achieving one's full performance potential" (Corbin, 1984, p. 906). "Equal opportunity" also means developing team sports, not just individual sports. Team sports are often perceived to be male in orientation (i.e., power, strength, physical contact, physical risk), and therfore, female participation is shumned because it compromises the social stereotype of femininity. Individual sports, however, are promoted because they maintain the femininity of female participants. If, however, team sports are provided, performance tends to be over-evaluated, and compared to male performance. High expectations exist to draw large crowds, and to justify the money budgeted when funds could be utilized in male programs. Many supporters of the men's programs complain that they are being short-changed of funds because of additions to female programs. Because of these pressures, females may have been lured into using ergogenic aids in order to prove 
themselves as real competitors.

The literature review presents a brief history of ergogenic aid use, and culminates with a description of ergogenic aid studies involving high school age athletes and their consumption of ergogenic aids.

\section{History of Ergogenic Aid Use}

The use of drugs to enhance athletic performance is not the domain of modern civilized society, as certain substances were used in antiquity and throughout the years to increase work capacity. Possibly the first recorded incident of use was in the Garden of Eden when Adam and Eve believed the apple would give them God-like powers (Williams, 1974, p. 7). The ancient Greeks ate sesame seeds, and the legendary Berserkers (Norse warriors who were believed to be invulnerable in battle) used bufotien, a hallucinogen, (Williams, 1974). The Andean Indians chewed coca leaves, while the Australian Aborigines chose the pituri plant for stimulation and anti-fatiguing effects (Williams, 1974). Milo of Crotona said in the sixth century B.C.: "Athletes tried to increase physical powers by eating meat that differed in quality depending on the event for which they were training" (Stokes, 1979, p. 96).

Later, during the Civil War, soldiers consumed large amounts of coffee to maintain their energy (Williams, 1974). From the early part of this century many athletes have used numerous agents to improve their performance. For example, the Russians first admitted to using anabolic substitutes as ergogenic aids in the 1960s (Stokes, 1979). "However, it is only in recent years that drug use in athletics has received considerable 
attention, probably because of the national and international drug problem as a whole" (Williams, 1974). One constantly hears about drug use to improve performance on all levels of athletics, whether it is college, professional or olympic athletes. Names of athletes like Ben Johnson, Brian Bosworth, and Lyle Alzado have appeared in the media in regards to ergogenic aid use.

\section{Studies of Ergogenic Aid Use}

Most of the studies addressing ergogenic aid use among adolescents in this century focus on anabolic steroids. Of particular focus in these studies is the general, high school population and the male athlete (Buckley, 1988, Corder, 1975, Fuller, 1987, Johnson, 1989, Terney and McLain, 1990, Windsor, 1989, and Yesalis, 1989). The investigator found no studies completed in regard to female athletes only and just two were found to specifically address the use of several types of ergogenic aids by high school athletes (Dymant, 1987 and Krochuk, 1989). It was therefore the objective of this study to focus on the prevalence of ergogenic aid use among female, high school athletes

Corder designed a questionnaire to measure drug use behavior in 1393 high school students in the Phoenix metropolitan area during the 19701971 academic year. The results of this study indicated anabolic steroid use was $\mathbf{0 . 7 \%}$. However, these figures were not specifically related to ergogenic use by athletes. The five year follow up study was administered to 1099 high school students. Of 208 high school athletes $4 \%$ indicated use of anabolic 
steroids in their training program; statistics were not provided for males and females separately.

In 1986, Newman presented his study entitled, "Michigan Consortium of Schools Student Survey" conducted in conjunction with Hazelden Research Services of Minneapolis. It was found that the rate of current or previous anabolic steroid use was $3 \%$ for all students, grades 8 , 10, and 12. According to the response of the seniors, $5 \%$ of the males and $1 \%$ of the females had used anabolic steroids.

Buckley (1988) estimated the prevalence of anabolic steroid use among male high school seniors to be $6.6 \%$, and that over two thirds of this user group initiated use when they were 16 years of age or younger. Users were more inclined to participate in school-sponsored athletics, in particular, football and wrestling. The largest percentage of users $(47.1 \%)$ reported that their main reason for using the drug was to improve athletic performanre. An 11-item, anonymous questionnaire was administered for data collection by homeroom teachers.

Another study addressing male adolescent anabolic steroid use was completed by Johnson, et al in 1989. Originally, this study included female respondents, but the data were not analyzed because only five indicated use of steroids out of a total of 914 female respondents. Instead, 853 male students were used in compiling results. These subjects were obtained from six Arkansas high schools. All subjects were in the eleventh grade and the group's racial mixture varied across schools. A self-report, anonymous, multiple-choice questionnaire was administered. The ten item questionnaire was completed at the beginning or end of a class period. 
These questions addressed perceptions of the physiologic effects of steroids, familiarity with complications associated with steroid use, sources of information about steroids, and reasons for personal use. Results indicated that approximately $11 \%(\mathrm{n}=95)$ had used or were using anabolic steroids. Eighty-four percent of steroid users were involved in competitive or noncompetitive sports. These subjects did not have an adequate understanding of the physiologic effects and potential complications of steroid use.

Yesalis, who has completed several studies in the area of anabolic steroid use among other populations, revealed in his 1989 study that $6.34 \%$ of twelfth grade males used anabolic steroids. He, not unlike other researchers, also used an anonymous, self-report survey, and it was also administered by the homeroom teacher. A total of 3,403 twelfth grade male students from both public and private high schools in eight demographic categories completed the survey. Fifty-seven percent of users perceived their strength to be greater than average, and $71 \%$ ranked their health very good or better than non-users of anabolic steroids. Approximately $40 \%$ of anabolic steroid users did not want anabolic steroid use in sports stopped even if they were assured their competitors were not using the drugs. Also, one out of four anabolic steroid users indicated their intentions to continue use regardless of health consequences.

One of the first studies to include females along with males in the data collection was Windsor in 1989. During physical education class, 1,010 anonymous surveys were distributed by coaches in 10 high schools of different socioeconomic status in the southwestern United States. Three percent of all high school students surveyed stated they used anabolic 
steroids. A total of $5 \%(n=23 / 462)$ of all males and $1.4 \%(n=6 / 439)$ of all females reported using anabolic steroids. When considering just athletes, $6.7 \%(n=20 / 299)$ of the male athletes reported anabolic steroid use, and .7\% $(n=2 / 277)$ of the female athletes reported anabolic steroid use. The general student population of higher socioeconomic status showed a greater overall anabolic steroid use ( $4.5 \%$ versus $1.9 \%)$.

Another high school study that examined the use of anabolic steroids which included females was completed by Terney and McLain in 1990. The high school in this study was located in a suburb of Chicago. A 29-question, anonymous survey was administered to 2,113 students during their physical education, driver's education, or health science class. The students were permitted 40 minutes to complete the questionnaire. Ninetyfour students (4.4\%) reported using anabolic steroids; 67 males (6.5\%) and 27 females (2.5\%) . Of those who participated in sports, $5.5 \%$ used steroids (6.6\% males, $3.9 \%$ females).

Only one study and one article were found that focused on a variety of ergogenic aids which included female high school athletes. The study, completed in the Cleveland area by Krochuk in 1989, surveyed 295 studentathletes attending 3 suburban high schools grades 9 through 12 . The anonymous questionnaire included the following ergogenic aids: anabolic steroids, amphetamines, and nutritional supplements. The mean age of subjects was 15.6 years, with a range of 13 to 18 years. Seventy-two percent of subjects were male, $66 \%$ were white, and $30 \%$ were black. Subjects were distributed equally among the four high school grade levels. Of the athletes surveyed, $49 \%$ played one sport, $34 \%$ played two sports, and $12 \%$ played 
three sports. Among athletes participating in one or more sports, the four most commonly played sports included football (42\%), basketball (19\%), track or cross country (18\%), and soccer $(12 \%)$. In general, young athletes were aware that certain agents may be used in an attempt to improve sports performance. One hundred forty-five respondents (55\%) had heard of athletes using anabolic steroids, and 62 (25\%) had heard of the use of amphetamines. One hundred forty-seven (58\%) were aware of the use of protein supplements, and $143(56 \%)$ were aware of the use of vitamins, all for the purpose of enhancing performance.

Overall, young athletes expressed negative views regarding the use of anabolic steroids and amphetamines. The majority of subjects believed that anabolic steroids and amphetamines were not effective and that their use was associated with a high degree of risk. Most young athletes felt that the use of these agents was not appropriate at any level of competition, and nearly all believed their coaches would disapprove of the use of these agents. However, a majority of subjects expressed positive views regarding the use of nutritional aids to enhance sports performance. The use of proteins and vitamins was perceived to be both effective and safe. Overall, $75 \%$ of subjects in Krochuk's study believed that it was appropriate for athletes to use these agents, and a majority of these subjects approved of the use of protein $(83 \%)$ or vitamins (73\%) for athletic enhancement at the high school level. A majority of subjects believed their coaches would approve of the use of nutritional supplements. Only four subjects (1.4\%) stated that they had taken anabolic steroids, and five subjects (1.8\%) claimed that they had used amphetamines. Approximately one third of those surveyed, 
however, stated that they had used protein $(35 \%)$ or vitamins $(33 \%)$ in this capacity. Furthermore, $56 \%$ of subjects reported that they would consider the use of supplemental protein, while $52 \%$ would consider the use of vitamin supplements. No consistent associations between student athletes' responses and age, sport played, and level of sports competition were observed. Similarly, there were no consistent associations between subjects' responses and classification of sport played, even when controlled for gender.

Dymant (1987) reviewed real and alleged ergogenic effects of some drugs and their side effects. The drugs reviewed were principle drugs misused by adolescent athletes, and included amphetamines, caffeine, anabolic and androgenic steroids, and vitamin and protein supplements. The investigator found no other study which addressed the use of a variety ergogenic aids by high school athletes specifically.

\section{Summary}

For generations athletes have used a variety of food additives, vitamins, substitutes to gain weight, add strength and enhance performance on the field (Corley, 1990). These substances do not substitute for hard work, intensive training, or natural ability, and they are available to anyone "with no tinge of unfairness and illegality associated with their use" (Corley, 1990). This is evident from the studies that show increased reported use of these substances among the high school population. The fact that most of these studies have focused on anabolic steroid use in males shows the need for more studies targeting the female population, especially 
the athletic female population. In addition, substances other than anabolic steroids need to be addressed. Studies surveying female high school athletes and their use of a variety of substances need to be performed and the results reported. 


\section{Chapter 3}

\section{Procedures}

The subjects who participated in the pilot study and main study are described in this chapter along with the survey design and statistical procedures that were used to estimate the prevalence of ergogenic aid use among female high school athletes.

\section{Subjects}

The sample surveyed for this study included 323 female, high school, interscholastic athletes, grades nine, ten, eleven, and twelve, who ranged in age from fourteen to eighteen years. The subjects attended six different high schools in one Santa Clara Valley district during the 1990-1991 school year.

\section{Development of the Questionnaire}

The questionnaire was made up of four parts (refer to Appendix A). The first part of the questionnaire consisted of three demographic questions relating to current age, grade, and the particular sport in which the subject participated during the 1990-1991 school year.

The second part of the questionnaire ( 5 questions) consisted of questions which determined if the subjects could identify individuals other than themselves who use ergogenic aids (performance-enhancing substances), and if so, to indicate those drugs from the list provided. In addition, the individuals were asked if they used ergogenic aids themselves, and if so, to identify them from the list provided. The ergogenic aids listed 
in this section included: amphetamines, anabolic steroids, analgesics (pain relievers), caffeine, diuretics or laxatives, electrolyte drinks (i.e. Gatorade, Power Burst, Exceed, etc.), protein or amino acid supplements, vitamin or mineral supplements, and specified others. Also, subjects were asked how often they used the particular agent according to a Leikert Scale. Choices included: never, once or twice, one time per month, one time per week, one time per day, three times per day, and other.

The third part of the questionnaire included two questions about why subjects used the agent. The response choices included: to decrease weight, to increase weight, to reduce fatigue, to improve appearance, to increase strength, to increase speed, to cope with pressure, to increase performance, for pleasure, peer pressure, to prevent/treat a sport-related injury, and other. This section also asked subjects to identify their main sources of information about such agents (from a coach, other athlete, medical professional, muscle magazine, TV, newspaper, specified other).

The last part of the questionnaire focused on the belief system of the individual. Eight questions were asked regarding the use of ergogenic aids: a) whether subjects approved of ergogenic aid use in athletics, b) whether subjects were aware of any undesirable side effects of ergogenic aids, c) whether subjects thought the agents were effective, d) whether subjects planned to participate in college athletics, e) whether subjects hoped to obtain a scholarship, and f) whether subjects would use ergogenic aids if they thought it would help obtain a college, athletic scholarship. This section also asked the individual to evaluate their personal health and strength. 


\section{Administration of the Survey}

The investigator received permission to conduct the study from the athletic director of the school district, the principle of each school, and the athletic director at each school involved in the survey via phone conversation and written confirmation (see Appendix B-J). The investigator sent a follow-up letter to the school district athletic director, and each of the school's principals and athletic directors confirming their cooperation in the study; a copy of the survey was also sent to the above individuals. The survey was reviewed by each of these people, and questions or concerns were addressed at a district athletic directors' meeting that the investigator attended. No revisions of the questionnaire or protocol were requested. The group determined that the questions were thorough, fair, and comprehensive in nature. At this time, it was determined where and when to administer the survey; it was further determined that consistency among schools was important.

Female athletes were asked by the athletic director to meet in the gymnasium during their normally scheduled study hall to hear the description of the performance enhancing drug study to be conducted throughout the school district, and to receive parental consent forms (see Appendix $\mathrm{K}$ ) as a requirement to participate in the study. The athletes were informed when and where to appear by the daily news bulletin read in their second period class by the teacher. Female athletes were asked to take the forms home, discuss participation with their parents, and return the signed form the next week at the same place and time if they wished to 
participate in the study. Emphasis was placed on maintenance of anonymity, and voluntary participation.

Female athletes given consent to participate in the study by their legal guardian were asked to report to the designated place, at the designated time, on a specific date through a daily bulletin announcement and signs posted in the girls' locker room. At the designated time and place, the athletic director introduced the administrator of the questionnaire, and then left the room. Subjects were read a prepared statement (see Appendix L) by the survey administrator (who was the same in each case) regarding background of the administrator, the title of the study, purpose of the study, optionality and anonymity of participation in the study, and directions for filling out the questionnaire. The questionnaires were then distributed to subjects.

When questionnaires were completed, subjects placed their answer sheet in a box at the front of the room and went to their next regularly scheduled class.

\section{Statistical Procedures}

Numerical information was tabulated and analyzed using simple frequency counts, percentages, and the Chi Square test of association on the Statistical Package for the Social Sciences (version 3.0) computer program. Chi Square tests were used because the data was categorical in nature; this non-parametric statistic assessed if there was a relationship between users' and non-users' responses to questions. The level of significance was set at $\mathrm{p}<.05$ divided by the number of Chi Square tests. Tables and graphs 
were developed to facilitate interpretation of the findings. For the purpose of this study, numerical values were rounded to one decimal place.

\section{Content Validity and Reliability of the Questionnaire}

Self-report methods have been shown to be valid for documenting drug use, especially for the age group of this study (Ausel, 1976; Bonito, 1976; Deaux, 1984; Edwards, 1977; Freedberg, 1980; Petzel, 1973; Polich 1979; and Stacy, 1985). When the drug use rates from self-report studies have been compared with external methods of documenting drug use (reports by others, blood, urine samples, etc.), the self-report use rates have been similar or only slightly lower than rates from the other methods (Buckley, 1988). The self-report methods used in this study allowed respondents to have complete confidentiality.

In addition, self-reports have widespread application primarily because other satisfactory and practical measures of drug use are usually unavailable (Stacy, 1985) or financially difficult (for instance, biochemical measures using blood or urine samples) to obtain.

To qualitatively examine the survey, two experts, who had conducted their own studies on drug use, reviewed the questionnaire. In addition, a research biologist, school psychologist, and high school teacher categorized each question of the survey under headings provided by the researcher. These categories were as follows: demographics, drug use, information on drugs, opinion-drug use, athletic future, and self-perception. Categorizations were $100 \%$ identical between the above groups; therefore, qualitatively the instrument appeared to have good content validity. This 
method of establishing validity was used because the instrument format varied throughout which prevented use of procedures such as factor analysis to quantitatively examine content validity. A pilot study was also conducted to establish data collection procedures. The procedures employed in the pilot study were as follows: Coaches at an area high school were asked to gather female volunteers from among their athletic teams to participate in a pilot study about performance-enhancing substances. These female athletes were requested to appear at study hall the following morning to respond to the survey. Sixteen female athletes appeared in study hall the following morming to participate in the pilot study. Volunteers were read the directions ( See Appendix L). Questionnaires were distributed. Subjects were allowed 15 minutes to complete the questionnaire. Subjects departed individually as they placed the completed questionnaires in a box at the front of the room. When all questionnaires were completed, the administrator collected the box and left the facility.

Reliability of a study is dependent upon the investigator's ability to give accurate directions and the subjects being able to understand and interpret the questionnaire. It is for this reason that a written protocol and statement of purpose was read to subjects and was contained within the study. 


\section{Chapter 4}

\section{Results}

No changes in protocol were deemed necessary following the pilot study since no problems or questions were encountered. However, question \#8 was added after the pilot study at the request of the thesis committee members. This question was added to eliminate ambiguity and to enhance the information gained from the questionniare.

What follows are the results of the pilot study as well as the main study.

Demographics of the pilot study sample

The pilot study included 16 female high school athletes, mean age $16.5 \pm 1.0$ years. The grade distribution was fairly even except for lack of representation of freshmen ( $0 \%$ freshmen, $31.3 \%$ sophomores, $31.3 \%$ juniors, 37.5\% seniors). Participation by sport was distributed as follows: $50 \%$ basketball; $25 \%$ softball, soccer, volleyball; $12.5 \%$ field hockey, track; $0 \%$ badminton, cross country, swimming, tennis.

\section{Prevalence of ergogenic aid use in the pilot study sample}

Over half $(56.3 \%)$ of the respondents said they knew someone who used performance-enhancing substances. The most common substance mentioned was electrolyte drinks (77.8\%). One third of the respondents (37.5\%) self-reported use of performance-enhancing substances, mostly electrolyte drinks, vitamin supplements, and caffeine. 
Factors related to performance-enhancing substance use among the pilot study sample

The most common reasons for taking the drug were to decrease fatigue $(83.3 \%)$ and to decrease weight $(50.0 \%)$. Sources of information about the substance were obtained mostly from television (43.8\%), other athlete (37.5\%), and doctor (31.3\%). Three quarters $(75 \%)$ of those surveyed thought it was unfair for athletes using performance enhancing substances to participate with substance-free athletes. Over half (56.3\%) responded that the effects of using performance-enhancing substances on the body were bad, however $37.5 \%$ responded that they didn't know the effects.

Future in athletics among the pilot study sample

Most respondents (68.8\%) said that they think ergogenic aids help improve an athlete's performance. Participation in college athletics was a goal of $81.3 \%$ of the athletes and $56.3 \%$ said they hoped to get a scholarship. In addition, $87.5 \%$ said they would not use substances to help them obtain a college athletic scholarship.

\section{Self-perception of the pilot study sample}

The athletes in the pilot study rated their overall health as very good and their strength as average compared to their peers.

\section{Relationships and correlations of the pilot study}

None of the data analyzed showed a statistically significant relationship between ergogenic aid use and the way subjects answered 
personal opinion questions. However, a moderate positive correlation existed between using an ergogenic aid and knowing the effects of the substance (Cramer's V=.63828). Eighty percent of non-users thought the effects of the substances were bad.

\section{Demographics of the main sample}

A total of 400 surveys were distributed among female athletes in the school district. A total of 323 surveys were returned for a studywide response rate of $81 \%$. Mean age of the subject was determined to be $15.64 \pm$ 1.08 years. Class representation was as follows: $24.5 \%$ freshmen $(n=79)$, $41.8 \%$ sophomores $(n=135), 26.9 \%$ juniors $(n=87)$, and $6.5 \%$ seniors $(n=21)$. These subjects were found to participate in 10 sports (See Table 1).

Prevalence of ergogenic aid use among the main sample

When asked if the subject knew of a female athlete who used performance-enhancing substances, 83.6\% $(\mathrm{n}=270)$ responded "no," while $15.8 \%(n=51)$ responded "yes". Of those $15.8 \%$ who said they knew a female who used performance-enhancing substances, the substances used are represented in Table 2.

Subjects self-reported use of performance-enhancing substances at a frequency of $20.1 \%$ ( $n=65)$. Of those subjects who used ergogenic aids, substances used were determined and are represented in Table 3. Of the $20.1 \%$ (65 subjects) who use ergogenic substances, the reasons for use were: $38.5 \%(\mathrm{n}=24)$ treatment or prevention of an injury, $24.6 \%(\mathrm{n}=16)$ to decrease 
Table 1: Self-reported participation by sport

\begin{tabular}{lcc} 
sport & \#subjects $(\mathrm{N}=323)$ & percent \\
softball & 88 & 27.2 \\
badminton & 75 & 23.2 \\
basketball & 67 & 20.7 \\
field hockey & 67 & 20.7 \\
soccer & 61 & 18.9 \\
track & 57 & 17.7 \\
swimming/diving & 50 & 15.5 \\
volleyball & 49 & 15.2 \\
tennis & 47 & 14.6 \\
cross country & 22 & 6.8 \\
\hline
\end{tabular}

Table 2: Ergogenic substances identified as being used by another female

\begin{tabular}{lcc} 
substance & \# subjects_(N=52) & percent \\
electrolyte drinks & 26 & 50.0 \\
pain tablets & 24 & 46.2 \\
pain creams/lotions & 22 & 42.3 \\
caffeine & 21 & 40.4 \\
special diets & 16 & 30.8 \\
vitamin supplements & 13 & 25.0 \\
protein supplements & 4 & 7.7 \\
water pills/laxatives & 3 & 5.8 \\
amphetamines & 3 & 5.8 \\
anabolic steroids & 1 & 1.9 \\
\hline
\end{tabular}


Table 3: Self-reported personal use of ergogenic aids substance \#subjects $(\mathrm{N}=65)$ percent

pain tablets pain creams caffeine special diets vitamin supplements electrolyte drinks protein supplements water pills/laxatives amphetamines anabolic steroids
33

31

25

23

21

17

8

3

3

0
50.1

47.7

38.5

35.4

32.3

26.2

12.3

4.6

4.6

0.0 
fat, $18.5 \%(n=12)$ for pleasure, $9.2 \%(n=6)$ to decrease weight, $9.2 \%(n=6)$ to relieve pressure, $7.7 \%(n=5)$ to increase performance, $4.6 \%(n=3)$ to increase speed, $4.6 \%(\mathrm{n}=3)$ to improve appearance, $3.1 \%(\mathrm{n}=2)$ to increase strength, $0 \%$ to increase weight, and $0 \%$ because of peer pressure.

The survey question addressing self-reported substance use for each sport immediately follows, but caution is urged in interpretation because only 90 subjects (28\%) answered the question. It is surmised that the question was not answered by most subjects because it might reveal their identity.

Of the 90 subjects who returned the survey, 71 subjects (78.9\%) said they used ergogenic aids, 19 subjects (21.1\%) said they did not use ergogenic aids. One subject (1\%) reported amphetamine use for track. No subjects reported anabolic steroid use for any sport. Pain creams were mostly used for softball (21.1\%), soccer (10\%), track (11\%), and volleyball (8\%). Pain tablets were mostly used for softball (16\%), and track (12\%). Caffeine use was reported mainly by softball players (9\%). Special diets were reported as used by basketball (6\%), softball (6\%), swimming (4.4\%)., and volleyball (4.4\%). Electrolyte drinks were most widely used by all sports, but especially softball (21.1\%), basketball (16\%), and soccer (12\%). Protein supplement isse was minimally reported by participants of any sport ( $9 \%$ of respondents, $n=8$ ). Vitamin supplements were predominantly used by softball players (8\%). Water pills and laxatives were not reported used by any subjects for any sport. For further breakdown of ergogenic aid use by sport, see Table 4. 
Table 4: Self-reported ergogenic aid use by sport.

$\begin{array}{lcccccccccc}\text { substance } & \mathrm{BD} & \mathrm{BK} & \mathrm{XC} & \mathrm{FH} & \mathrm{SB} & \mathrm{SOC} & \mathrm{SW} & \mathrm{TN} & \mathrm{TR} & \mathrm{VB} \\ \text { amphetamines } & - & - & - & - & - & - & - & - & 1 \% & - \\ \text { steroids } & - & - & - & - & - & - & - & - & - & - \\ \text { pain creams } & 2 \% & \mathbf{9} \% & 1 \% & 6 \% & 21.1 \% & 10 \% & 3 \% & 2 \% & 11 \% & 8 \% \\ \text { pain tablets } & 2 \% & 8 \% & 1 \% & 1 \% & 16.0 \% & 8 \% & 6 \% & 1 \% & 12 \% & 4.4 \% \\ \text { caffeine } & 2 \% & 4.4 \% & - & 2 \% & \mathbf{9} \% & 2 \% & 1 \% & 1 \% & 3 \% & 4.4 \% \\ \text { special diet } & - & 6 \% & - & - & 6 \% & 1 \% & 4.4 \% & 1 \% & 3 \% & 4.4 \% \\ \text { electrolytes } & 2 \% & 16 \% & - & 8 \% & 21.1 \% & 12 \% & 2 \% & 1 \% & \mathbf{9} \% & 6 \% \\ \text { P supplements } & - & 1 \% & - & 1 \% & 2 \% & 1 \% & - & 1 \% & 1 \% & 1 \% \\ \text { vit supplements } & 1 \% & 6 \% & 1 \% & 3 \% & 8 \% & 4.4 \% & 4.4 \% & 3 \% & 6 \% & 6 \% \\ \text { water pills/ } & - & - & - & - & - & - & - & - & - & - \\ \text { laxatives } & & & & & & & & & \end{array}$


Factors related to performance-enhancing substance use among the main sample

Responses differed between users and non-users and their sources of information about performance-enhancing substances. Users reported family members $(26.2 \%, \mathrm{n}=17)$, a doctor $(24.6 \%, \mathrm{n}=16)$, and television (21.5\%, $\mathrm{n}=14$ ) as their main sources of information about ergogenic aids (see Table 5). Non-users, on the other hand, reported TV (30.6\%,n=79), magazines $(19.8 \%, \mathrm{n}=51)$, and newspapers $(16.7 \%, \mathrm{n}=43)$ as their main sources of information regarding performance-enhancing substances.

When asked if subjects thought it was fair for substance users to compete in the same contest as non-users, $83.3 \%(n=269)$ said it was not fair ( $86.6 \%$ non-users, $13.4 \%$ users), and $12.4 \%(n=40)$ said it was fair $(60 \%$ users, $40 \%$ non-users) for users to compete in the same contest as nonusers. Two hundred and seventeen of the survey respondents, $67.2 \%$ (91.2\% non-users, $8.8 \%$ users) said they thought the effects of performanceenhancing substances were bad. Ninety subjects, who comprised $27.9 \%$ of the surveyed population ( $61.1 \%$ non-users, $38.9 \%$ users) said they did not know the effects of ergogenic aids, and $2.5 \%$ (100\% users) responded that the effects were good. Despite possible effects, $48 \%$, one hundred and fiftyfive subjects ( $74.2 \%$ non-users, $25.8 \%$ users), thought these substances helped performance, and $44.9 \%$, one hundred and forty-five subjects $(86.2 \%$ non-users, $13.8 \%$ users), thought these substances did not help performance. 
Table 5: Self-reported sources of information about performance-enhancing substances

\begin{tabular}{lrrrr} 
source & \% users & $\mathrm{n}=$ & \% non-users & $\mathrm{n}=$ \\
coach & & & & \\
teacher & 18.5 & 12 & 8.5 & 22 \\
athlete & 7.7 & 5 & 14.0 & 36 \\
doctor & 16.9 & 11 & 7.0 & 18 \\
family member & 24.6 & 16 & 8.5 & 22 \\
newspaper & 26.2 & 17 & 8.9 & 23 \\
TV & 7.7 & 5 & 16.7 & 43 \\
magazine & 21.5 & 14 & 30.6 & 79 \\
none & 10.8 & 7 & 19.8 & 31 \\
friend & 15.4 & 10 & 12.8 & 9 \\
& 3.1 & 2 & 3.5 & \\
\hline
\end{tabular}


Future in athletics among the main sample

Participation in college athletics was a goal of $71.8 \%(n=232)$ of the respondents (20.7\%, $\mathrm{n}=48$, were ergogenic aid users). Those hoping to obtain a college athletic scholarship encompassed $51.1 \%(n=165)$ of those surveyed (21.2\% were users). An overwhelming $87 \%(n=281)$ of these female athletes said they would not use performance-enhancing substances to obtain a college scholarship ( $75.8 \%$ non-users, $24.2 \%$ users), while $9.6 \%$ $(n=31)$ said they would use ergogenic aids to obtain a college scholarship (61.3\% users, $38.7 \%$ non-users).

\section{Self-perception of the main sample}

Overall, these female athletes reported their health as good to very good. Strength was rated as average to above average (see Tables 6 and 7).

\section{Relationships and correlations of the main sample}

Because the data collected was categorical in nature, the Chi-Square statistic was used to assess the relationship between ergogenic aid use and the way personal opinion questions were answered (items 9 through 18 on the questionnaire). Cramer's V or Phi statistics were utilized to determine the strength of the relationship. The Chi-Square statistic was included in the outcome if its expected frequency was less than $20 \%$. The level of significance was set at $\mathrm{p}<.05$ divided by the number of Chi Square tests, before the study began because of the experimental nature of the research.

None of the data analyzed showed a statistically significant relationship between ergogenic aid use and the way subjects answered personal opinion questions. However, a mild, positive correlation did exist 
Table 6: Self-reported perception of health

\begin{tabular}{lccc} 
rating & \% subjects $(\mathrm{N}=323)$ & \% users & $\%$ non-users \\
excellent & 15.5 & 16.0 & 84.0 \\
very good & 58.9 & 20.8 & 79.2 \\
good & 34.4 & 20.7 & 79.3 \\
fair & 8.7 & 21.4 & 78.6 \\
poor & 0.3 & 100.0 & 0.0 \\
\hline
\end{tabular}

Table 7: Self-reported perception of strength

\begin{tabular}{lccc} 
rating_ & $\%$ subjects $(\mathrm{N}=323)$ & $\%$ users & $\%$ non-users \\
>average & 29.4 & 24.2 & 75.8 \\
average & 68.4 & 18.6 & 81.4 \\
<average & 1.2 & 25.0 & 75.0 \\
& & & \\
\hline
\end{tabular}


between using an ergogenic aid, and thinking it was fair for users to compete with non-users of ergogenic aids (Phi=.39462). In addition, a moderate, positive correlation existed between using an ergogenic aid and knowing the effects of the substance (Cramer's V=.47152). Of those subjects who believed the effects of ergogenic aids were good, $100 \%$ were users of the substances. Conversely, of those subjects who thought the effects of performance enhancing substances were bad, $91.2 \%$ were non-users of the substances. 


\section{Chapter 5}

Conclusions and Discussion

The purpose of this study was to investigate the prevalence of ergogenic aid use among female high school athletes. What follows in this chapter is a summary of procedures and findings, conclusions, discussion, and recommendations for further study.

\section{Summary of procedures}

Three hundred and twenty-three female, high school athletes from a Santa Clara Valley high school district served as subjects in this investigation. Subjects asked to participate in the study received a written and verbal explanation of the study and completed parental, informed consent. All participants were asked to fill out a two-page, multiple choice questionnaire which required approximately ten minutes to complete. Information pertaining to performance-enhancing substance use, personal opinion of ergogenic aid use, future in athletics, self-perception, and demographic data was collected.

\section{Summary of findings}

The mean age of the subject was approximately sixteen years. About $20 \%$ of these athletes responded that they used ergogenic aids. Of these substances, the most frequently cited were pain relievers, caffeine, and nutritional supplements. The treatment or prevention of an injury, or 
weight concerns were the most prevalent reasons for their use. It was interesting to note that peer pressure was not one of their most frequent reasons for using an ergogenic aid. Substance users reported that family members and doctors were their main source of information about the ergogenic aids, but non-users relied on the media for their knowledge. Most of the subjects felt it was not fair for users of ergogenic aids to compete in the same contest as non-users. Of those who thought it was fair to compete in the same contest, the majority were users of ergogenic aids. Most of the users thought the effects of the performance-enhancing substances were good, whereas the non-users felt the effects were bad. Ninety of these female athletes reported that they did not know the effects of these substances. Despite the prevalence of use among these female, high school athletes, most of them revealed they would not use them to try to obtain a college scholarship. Overall, user or non-user, these athletes rated their health as good to very good, and their strength as average. There was no significant relationship between ergogenic aid use and the manner in which the survey questions were answered. However, a mild, positive correlation did exist between using an ergogenic aid and thinking it was fair to participate in the same contest as non-users. A moderate, positive correlation also existed between using an ergogenic aid and thinking the effects of these performance-enhancing substances were good; non-users believed the effects were bad. 


\section{Conclusions}

Based upon the findings of this study, and within the limitations stated, the following conclusions are made:

1. Although it was anticipated that ergogenic aid use was present among the female, high school athletic population, it was surprising to see the prevalence of use at about $20 \%$. The results were expected to be under $10 \%$, but was probably higher given the wide range of substances called ergogenic aids.

2. Anabolic steroid use was not self-reported, but amphetamine use was self-reported at almost 5\%. Female athletes generally do not want to bulk up and gain weight, but would rather lose weight. Therefore, it follows that anabolic steroids, which add weight and muscle mass, would not be one of the more prominant choices. 3. A major finding of this study was the early age of ergogenic aid use (mean age $15.6 \pm 1.1$ ). It is a prevalent belief that most ergogenic aid users are college or elite athletes, and of the male gender.

4. It was surprising that the main source of information about ergogenic aids for users were family members and doctors, and that non-users relied on the media (television, magazines, newspapers). The exact opposite was expected since the media is so often scolded for being a bad influence on the American youth.

5. Of those subjects who thought it was unfair for substance users to compete in the same contest as non-users, a majority were non- 
users. Of those who thought it was fair, most subjects were users of ergogenic aids.

6. Overall, the subjects thought the effects of ergogenic aids were bad. A surprising number did not know the effects of these substances.

7. Subjects were undecided as to whether or not the substances actually helped performance.

8. Female high school athletes would like to be collegiate, scholarship athletes, but surprisingly, would not use ergogenic aids to increase their chance of success.

9. Ergogenic aid users ranked their general health and strength above their peers.

10. This study provided important data in documenting trends in the ergogenic aid use habits of female, high school athletes. However, data may not be representative of the entire United States population of female, high school athletes, because data was collected in only one state, in one county, and in one school district.

11. It is possible that some athletes may have under- or over-reported their ergogenic aid use. The data does, however, provide coaches, athletic trainers, doctors, teachers, and administrators with information that will aid in design of intervention, counseling, and education programs. 


\section{Discussion}

The major finding in this study was that a portion (about 20\%) of female, high school athletes use ergogenic aids to enhance athletic performance. Because of the young age of these athletes, intervention programs need to be initiated in the ninth grade, and as early as the sixth or seventh grades. Education programs are always mentioned, but questions arise as to which classes should address the topic: physical education, health, or science. In addition, current curriculum content seems narrow. Not only should the risks and side effects of illicit drugs be discussed, but also choices should be given in terms of the alternatives to these substances; for instance, a balanced diet, strength and conditioning programs, stretching, and physical training methods. In addition, control of psychological processes should be taught. Cognitive skills, strategies to increase athletic potential, relaxation techniques, mental imagery and goal setting might be some viable alternatives. Potential harm of these substances is usually discussed by educators, but ethical and philosophical inquiry dealing with fairness and cheating, advantage, competition, sacrifice, the "winning edge," and legality should also be included. Peer counseling might also be appropriate.

Another finding of this study was that users of ergogenic aids rely on certain people for their information; doctors, parents, family members, and coaches. These people, especially health care providers, need to become more knowledgeable about the substances so they may provide guidance to these youth. Also, they need to be aware of the signs and symptoms associated with the use of such aids so as to intercede at critical times. 
Such "red flags" include: secretive behavior, mood swings, sudden and dramatic weight gain or loss, puffiness, and gynecological changes (Yesalis, 1989). Contrary to popular belief, the media seems to be doing a good job informing these youth about the bad effects of most periormanceenhancing substances, as is revealed in this study by the fact that most nonusers rely on TV, magazines, and newspapers for their information about ergogenic aids.

Society must change its focus to the growth experience of sport instead of its fixation on winning and female stereotypes. A more reasonable perspective on appearance and sports participation is needed.

The last area of discussion addresses drug testing and controls or sanctions against certain drugs and ergogenic aids. The National Collegiate Athletic Association (NCAA) and United States Olympic Committee (USOC) have already established strict guidelines to monitor and limit performance-enhancing substance use. Perhaps the high school athletic federations are the next in line for adapting some type of regulatory system. However, it is doubtful due to the high costs of maintaining such a program. High schools already have difficulty funding the athletic programs. Funds are needed for priorities such as facility maintenance, coaches fees, uniforms and equipment, referees fees, athletic trainer fees, and medical supplies. The other disadvantage to such a program would be its inability to protect privacy and ever-increasing liability costs. 
Recommendations for further study

The use of ergogenic aids to increase athletic performance is a confounding and controversial topic for discussion, Research is continuous on the different drugs used to increase work capacity and their effects. Much of this research is inconclusive and contradictory in nature. Experimental design and procedure must be evaluated and guided more stringently to allow valid research results.

Health professionals, coaches, and parents must be better educated to detect the signs and symptoms of substance use, and the procedures necessary to help the athlete once use is confirmed.

Psychologists need to work with peer counseling groups, and present literature suited to those who work specifically with athletes so as to make available optional methods of enhancing performance without drugs. Training coaches and athletes in relaxation, visualization, and other mental imagery techniques might offer better alternatives than ergogenic aids.

In addition, a more representative sample of female, high school athletes in the United States could be drawn from different regions of the country. A larger sample size increases the chance of making valid generalizations of findings.

It would also help those surveyed if the classifications of ergogenic aids were better defined by adding specific examples of each classification.

For future studies, individual sport teams might be surveyed individually to determine which substances are prevalent among different sport forms. 
Another recommendation is that format be the same for each question of the survey so a factor analysis can be carried out. This statistical measurement assesses validity, determining if the questionnaire is a good tool.

The last recommendation for further study is to add "athletic trainer" to the list of sources of information about ergogenic aids. Athletic trainers have contact with athletes on a daily basis and can be knowledgeable sources for athletes to rely upon for information about performance enhancing substances.

\section{Summary}

The results of this study show that there is an obvious need for continued research in the area of ergogenic aid use, especially among the female high school athletic population; they represent a special group with special needs. As professionals in charge of the welfare of these individuals, it is the duty of athletic trainers, coaches, educators, administrators and parents to do their best to insure the athlete's health, and thus, their livelihood. 


\section{References}

Ausel, S., Mandell W., Mathias, L. (1976). Reliability and validity of selfreported illegal activities and drug use collected from narcotic addicts. International Journal of Addictions, 15, 325-336.

Bonito, A.J., Nurco D. N., Schaffer J.W. (1976). The veridicality of addicts' self-reports in social research. International Journal of Addictions, 11, 719-724.

Buckley, W.E. (1988). Estimated prevalence of anabolic steroid use among male high school seniors. Joumal of the American Medical Association, 260(23), 3441-3445.

Corbin, C.B. (1984). Self-confidence of females in sports and physical activity. In Clinics in Sports Medicine, 3(4), 895-908.

Corder, B.W., Dezelsky, T.L., Toohey, J.V., and DiVito, C.L. (1975). Trends in drug use behavior at ten central Arizona high schools. Arizona. Journal of Health,_Physical Education, and Recreation, 18, 10-11.

Corley, F.G. (1990). Steroid use by athletes shows poor judgement, lost integrity. Texas Medicine, 86(3), 4.

Deaux, E., Callaghan, J.W. (1984). Estimating statewide health-risk behavior: A comparison of telephone and key informant survey approaches. Evaluation Review, 8, 467-492.

Duda, M. (1986). Female Athletes: Targets For Drug Abuse. The Physician and Sportsmedicine, 14(6), 142-146.

Dymant, P.G. (1987). The adolescent athlete and ergogenic aids. Special issue: Medication and drug use in adolescence. Joumal of Adolescent Health Care, 8(1), 68-73. 
Edwards, G., Orford J., Egert S. (1977). Alcoholism: A controlled trial of treatment and advice. Journal of Studies of Alcohol, 38, 1004-1031.

Freedberg E., and Johnston, W. (1980). Validity and reliability of alcoholics' self-reports of use of alcohol submitted before and after treatment. Psychological Report, 46, 999-1005.

Fuller, J.R. \& LaFontain, M.J. (1987). Performance-enhancing Drugs in Sport: A Different Form of Drug Abuse, Adolescence, 22(88), 969-976.

Hallagan, J.B., Hallagan, L.F., and Snyder, M.B. (1989). Anabolicandrogenic steroid use by athletes. New England Joumal of Medicine, 321(5), 1042-1045.

Hamilton, E., Whitney, E.N., and Sizer, F.S. (1988). Nutrition: Concepts and Controversies (4th ed.). St.Paul: West Publishing Co.

Harris, D.V. (1987). The female athlete. In Sport Psychology by J.R.May and M.J.Asken. New York: PMA, 99-116.

Haycock, C.E. (1980). Sports medicine for the athletic female. New Jersey: Medical Economics.

Hogan C.L. (1979). Title IX: From here to equality, 1977. in Sport and contemporary society: an anthology by D. Stanley and N. Eitzen. New York: St. Martin's, 421.

Johnson, M.D. (1989). Anabolic steroid use by male adolescents. Pediatrics, 83(6), 921-924.

Kibble, M.W. and Ross, M.B. (1987). Adverse effects of anabolic steroids in athletes. Clinical Pharmacy, $\underline{6}(9), 686-692$.

Krochuk, D.P. (1989). High school athletes and the use of ergogenic aids. American Journal of Diseases and Children, 143,486-489. 
The Merck Manual (15th ed.). New Jersey: Merck and Co., Inc. 1987.

National Strength and Conditioning Association (1989). Position paper part

I: Strength training for female athletes. NSCA Journal, 11(4), 43-55.

Newman, M. (1986). Michigan Consortium of Schools Student

Survey. Minneapolis, Hazelden Research Services.

Percy, E.C. (1977). Athletic aids: Fact or fiction. Canadian Medical

Association Journal, 117, 601-605.

Petzel T.P., Johnson J.E., McKillip J. (1973). Response bias in drug

surveys. Joumal of Consulting_and Clinical Psychology, 40, 437-439.

Polich, J.M., Armor, D., and Barker H. B. (1979). The course of alcoholism: Four years after treatment. Santa Monica, California, The RAND Corp.

Stacy, A.W., Widaman, K.F., Hays, R. and DiMatteo, M.R.(1985).

Validity of self-reports of alcohol and other drug use: A multitraitmultimethod assessment. Journal of Personality and Social

Psychology, 49(1), 219-232.

Stokes, P.G. (1979). A guide to sports medicine. New York: Churchill Livingstone.

Taber's Cyclopedic Medical Dictionary (1985, 15th edition) F.A. Davis Co., Philadelphia..

Terney, M.A., and McLain, L.G. (1990). Use of anabolic steroids in high school students. American Journal of Diseases and Children, 144, 99-103.

Webster's Medical Dictionary (1977). New York: Galahad Books. 
Williams, M.H. (1974). Drugs and athletic performance. Springfield, IL: Charles C. Thomas.

Windsor, R. and Dumitru, D. (1989). Prevalence of anabolic steroid use by male and female adolescents. Medicine and Science in Sport and Exercise, 21(5), 494-497.

Yesalis, C.E. (1989). Anabolic steroid use: indications of habituation among adolescents. Journal of Drug_Education, 19(2), 103-116. 


\section{APPENDIX A THE QUESTIONNAIRE}

Dear student,

We are interested in determining the level of use of performance enhancing substances among female high school athletes. In order to successfully carry out this project we need as many people as possible to complete this questionnaire and everyone who does so is helping the outcome of this study.

Participation is completely voluntary. The questionnaire is completely anonymous. DO NOT PUT YOUR NAME ONIT. The answers are confidential. The completed questionnaire will not be seen by any faculty or staff from this school. When you complete the questionnaire, place it in the box at the front of the room.

Thank you for your help.

\section{USE OF PERFORMANCE-ENHANCING SUBSTANCES QUESTIONNAIRE}

1. What is your current grade level?

a. Freshman

b. Sophomore

c. Junior

d. Senior

2. What is your current age?

a. 13

b. 14

c. 15

d. 16

e. 17

f. 18

g. $>18$

3. Which school sports did you participate in this year?
a. badminton
g. swimming
b. basketball
h. tennis
c. cross country
i. track
d. field hockey
j. volleyball
e. softball
f. soccer
k. other (specify)

4. Do you know any female who uses performance-enhancing substances?
a. yes
b. no

5 . If yes to $\# 4$, which ones?
a. amphetamines (speed)
b. anabolic steroids
g. electrolyte drinks (Gatorade, Power Burst, etc.)
c. pain creams or lotions
h. protein supplements
d. pain tablets (aspirin, etc.)
i. vitamin supplements
e. caffeine
f. special diet
i. water pills or laxatives
k. other (specify)

6. Do you use performance enhancing substances?
a. yes
b. no 
7. If yes to $\# 6$, which ones? How often? (please chock)

other

once or 1 time a 1 time a $2-3$ times 1 time 3 times

a. amphetamines

b. anabolic steroids

c. pain creams or lotions

d. pain tablets

e. caffeine

f. special diet

g. electrolyte dinks

h. protein supplements

i. vitamin supplements

j. water pills or laxatives

$k$. other

\section{never twice month woek a woek a day aday}

8. If you use performance-enhancing substances, which ones for which sports?

\begin{tabular}{|c|c|c|c|c|c|c|c|c|c|c|c|c|}
\hline amphatamines & & D:B & $R T$ & C! & $H:$ & $\mathbf{S B}$ & 580 & CS & N! & & & IVE: \\
\hline anabolle sterolds & & $T$ & $\because$ & t! & 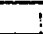 & & T & 7 & : & & & \\
\hline pain creams & & 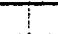 & - & & 7 & & & & & & & \\
\hline pain tablats & 1 & $i$ & i & & 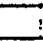 & & 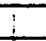 & . & & & & 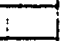 \\
\hline atton & 1 & $i$ & 1 & : & 1 & & i & 1 & : & ' & & i \\
\hline spectal dlol & $\bar{i}$ & $\bar{\vdots}$ & $i$ & $i$ & 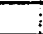 & & $!$ & $\div$ & $!$ & $\bar{\vdots}$ & & $\bar{i}$ \\
\hline elactrobte drnks & $T$ & $T$ & $!$ & $\bar{i}$ & 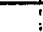 & & $\bar{\vdots}$ & ! & $\bar{i}$ & 1 & & \\
\hline proteln supplemems & & 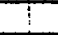 & $T$ & $T$ & 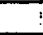 & & t & $i$ & 5 & & & $t$ \\
\hline vitamln supplomems & & $\bar{\vdots}$ & $i$ & $\overline{!}$ & 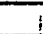 & & $\bar{i}$ & $!$ & 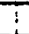 & & & $T$ \\
\hline water pillsitaxatives & & & & 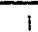 & 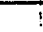 & & $i$ & -1 & & & & \\
\hline
\end{tabular}
$B D=$ badminton
FHefield hockey
TR=track
$B K=$ basketball SOC=soccer $S B=$ softball $S W=$ swimming $V B=$ volleyball
TN=tennis
$X C=$ cross country

9. If you have ever used performance enhancing substances, what is the main reason?
a. to decrease weight
b. to increase weight
f. to increase strength
c. to improve appearance
g. to increase speed
d. to reduce fatigue
e. to prevent/treat sport-related injury
h. to cope with pressure
i. to increase overall periormance
j. for pleasure
k. peer pressure
I. other (specify)

10. What is your source of information about performance enhancing substances?
a. coach
b. teacher
f. newspaper
c. other athlete
d. doctor
g. TV
e. family member
h. magazine
i. none
j. other (specify)

11. Do you think it is fair for athletes using performance enhancing substances to participate with substance-free athletes?
a. yes
b. no 
12. Do you think the effects of using performance enhancing substances on your body are:
a. good
c. don't know
b. bad

13. Do you think performance enhancing substances help an athlete's pericrmance?
a. yes
b. no

14. Do you plan to participate in college athletics?
a. yes
b. no

15. If yes to $\# 13$, do you hope to obtain an athletic scholarship?
a. yes
b. no

16. Would you use performance enhancing substances if you thought it would help you obtain a college athletic scholarship?
a. yes
b. no

17. How would you rate your overall health status compared to your peers?
a. excellent
d. fair
b. very good
e. poor
c. good

18. How would you rate your overall strength compared to your peers?
a. greater than average
b. average
c. less than average

This ends the questionnaire. After rechecking to make sure you have answered all the questions, place your survey in the box at the front of the room. Again, thank you for your help in this survey. 


\section{APPENDDX B \\ LETTER OF CONEIRMATION-PRINCIPAL 1}

Dear Sir or Madame,

I was very hapoy to allow Mary Brikich to utilize

High School's female atiletes as part of her thesis stucy. She was very professional in her conduct, and worked well wi th cur athletes. I hope our student's part aided in a sncessiul. stuciy.

sircerelv.

Prircizal

Hign scincol 


\section{APEETIDIX C \\ LETTER OF CONEIRMATION-PRINCIPAL 2}

Mary M. Brkici, ATC

Heed Traine- High School

To whem it Way Concern:

Marl Brkich contacted me saveral veeks aço to ask cemission and ny succort for her thesis project "studying the use of ergogenic aid use among female higi scisool atiletes in tid

Higin Schcoi Distzict".

I told hel

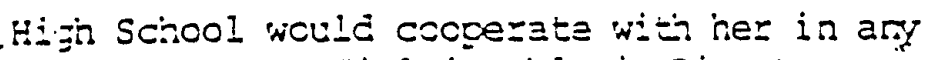
'wey and that sie should contact cur Gi=ls' ithlet:c Dirsctor, to set everginirg up.

Evezpting rient as plannes; Mafl got her inzornation and was haceg to participate in the projest.

$$
\text { sixesely, }
$$


APPENDIXD

\section{LETTER OF CONEIRMATION-PRINCIPAL 3}

Mary M. Brkich, ATC

Bead Trainer,_High School

Dear Mary:

Please be advised that

High school is in full support

of your study of the use of ergogenic aids among female high school athletes in the_ Aigh School District.

Yoid have my permission to conduct this study at

We expect you to exercise confidentiality in your

study and that the results and answers to questions be unconnecred to individual students.

I will be very interested in the results of your study.

Sincerely,

Prancipa! 


\section{LETTER OF CONEIRMATION-PRINCIPAL 4}

To whom It May Concern,

The request to survey

students was granted to Mazy Brkich in order to complete her thesis project.

Sincezely,

Principa! 
APPENDDXE

\section{LETTER OF CONEIRMATION-PRINCIPAL 5}

To Whom It May Concern:

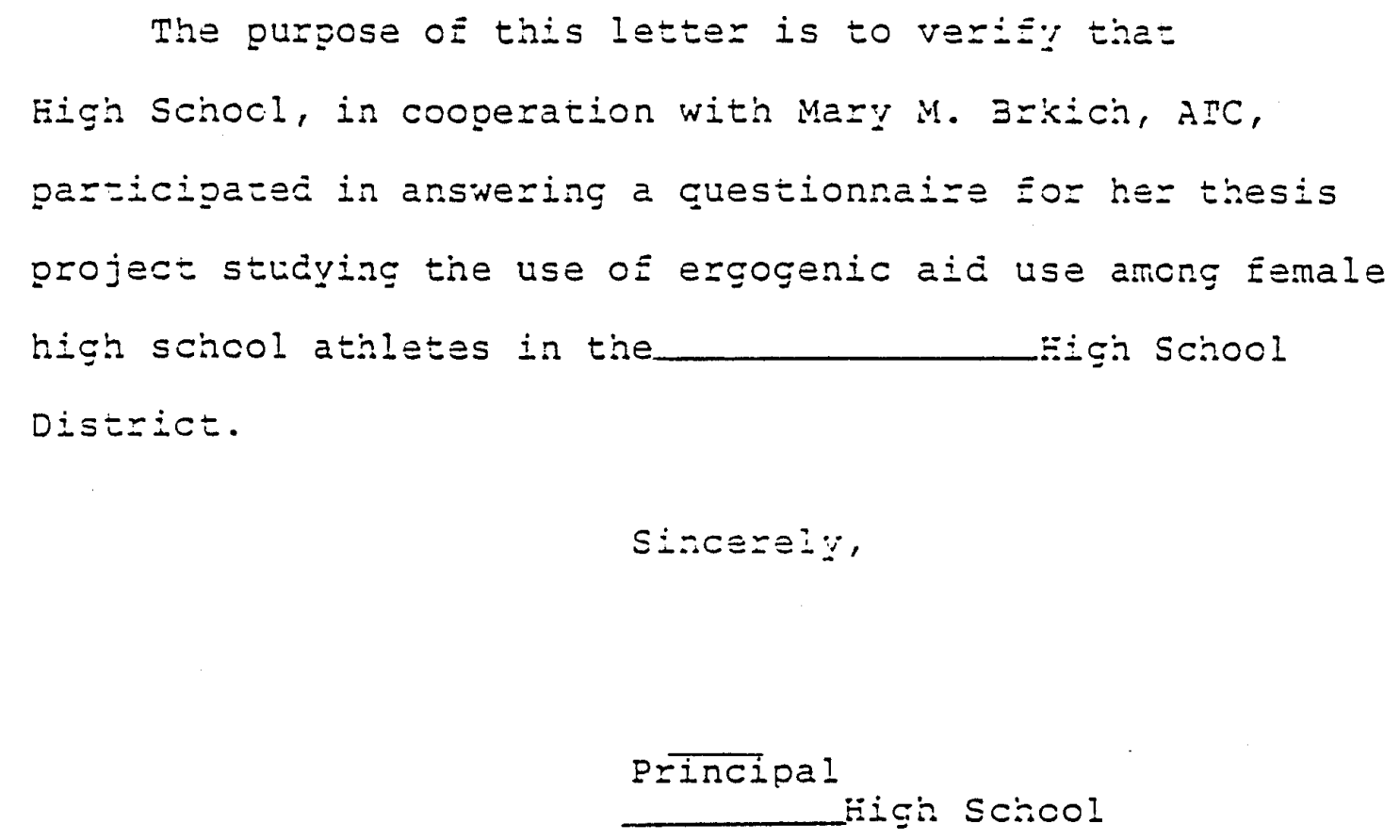

The purpose of this lettez is to vezíg tha: Eigh Schocl, in cooperation with Mary M. 3rkich, AIC, par=icipared in answexing a questionnaize Đoz hEz thesis project stliying the use of ergogenic aid use among Eemale high schcol athletes in the _agi school Disこニict. Hisis sciscol 


\section{APPENDIX G \\ IETWTER OF CONEIRMATION-ATHLETIC DIRECTOR 1}

MAET Y. BXTCE, ATC

Eid TIDTER,

MS. BEKICE,

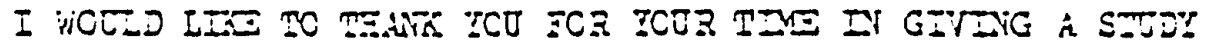

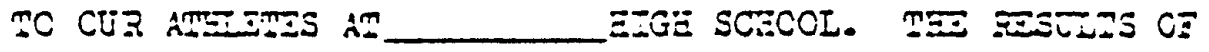

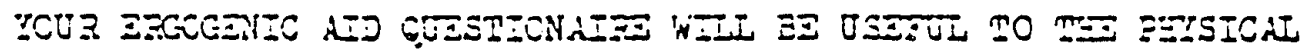

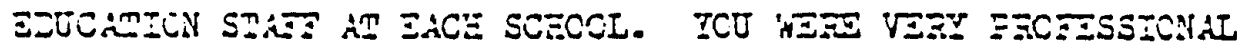

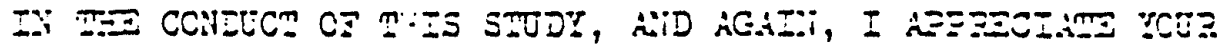

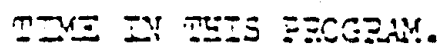

EX:CE:EY,

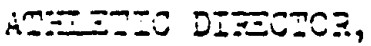




\section{LETTER OF CONEIRMATION-ATHLETIC DIRECTOR 2}

Mary M. Erkich, ATC

Head Trairier

DearMe. Erkich,

It was a pleasurs ior the Athietco cepertment a anc mysali to take pert in your thes a suco l hoce that the

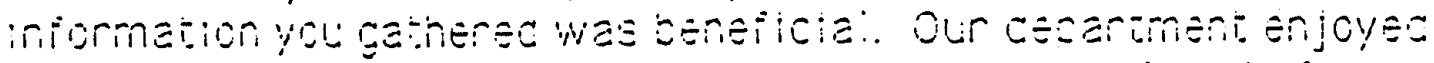
working with you, and we lock iorwarc to ce irg rovolved in ilure

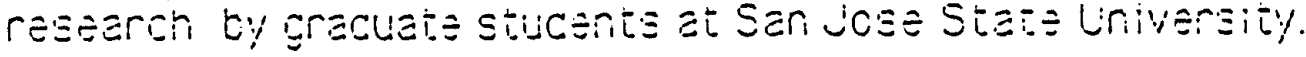

Eood iuck with ycur researcin.

Sincoroly, Athistic D OrEotor 
APPENDDXI

LETTER OF CONEIRMATION-ATHUETIC DIRECTOR 3

Mary M. Erkich, aTC

Heat Trainer.

De an Mary:

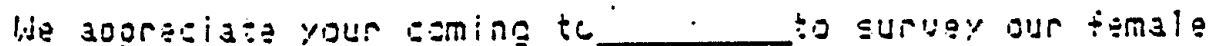

stitie a

usa of erocọanic al

within our schoci distriet. As eduestors we ato sotsene

interss:z.t in prsmoting siudias and programs that hooptully will

bensitit the young pesole in cur society.

Our compliments to yau for an exesilint prosentition during

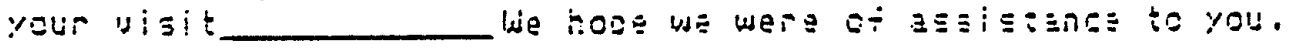

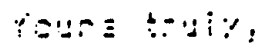

Eiris'p.e. Dejt. 


\section{APPENDIX] \\ LETTER OF CONEIRMATION-DISTRICT DIRECTOR OF PE}

To Whom It May Concern

I wish to announce san Jose State University and the

High School District, in a cooperative effort, will jointly conduct a stucy of:

Prevalence of Erqogenic Aids Use Among Female High School Athletes in the High School District

This study will be conducted by Mary Brkich, Laad Athletic Trainer from Hign School and San Jose State Cunirersity. Assisting and supervising Brkich will be Richard G. Deivert, PA.D. ATC, Assistant Professor, Department of Human Performance, and myself.

ive, in the have long felt the need for this type of researci/stucy anci are eagerly awaiting the results.

Sincer?!?.

District Dizector

Physical Ecucation 
APPENDIX K

CONSENT FORM

\section{AGREEMENT TO PARTICIPATE IN RESEARCH SAN JOSE STATE UNIVERSITY}

RESPONSIBLE INVESTIGATOR: Mary Brkich, graduate student

TITLE OF PROTOCOL: The Prevalence of Ergogenic Aid Use Among Female High School Athletes in the Santa Clara Valley.

Your child is invited to participate in a research study that is investigating the prevalence of performance enhancing substance use among female high school athletes in a Santa Clara Valley High School District. A survey will be distributed that includes a list of dangerous and illegal drugs, such as steroids and amphetamines, that your child may or may not be using. The results of this study should further our understanding of which substances female athletes use to enhance performance while participating in athletics, why they use them, and how often.

I understand that

1) I will be asked to fill out an anonymous questionnaire that will take approximately ten minutes to complete during study period in the gymnasium at my high school.

2) there are no anticipated risks involved in participating in the study.

3) the possible benefits of this study to my child are: a) a further understanding of young female athletes by their teachers, coaches, athletic trainers and parents, so that they may educate the female athlete about performance enhancing substances, b) their benefits and side effects, and c) alternatives to using such substances.

4) the results from this study may be published, but any information from this study that can be identified with me will remain confidential and will be disclosed only with my permission or as required by law.

5) any question about my participation in this study will be answered by Mary Brkich at (408)866-8586. Complaints about the procedures may be presented to Rich Deivert, Ph.D. ('Thesis advisor) at (408)924-3040. For questions or complaints about research subject's rights, or in the event of 
research-related injury, contact Serena Stanford, Ph.D (Associate Academic Vice President for Graduate Studies \& Research) at (408)9242480 .

6) my consent is given voluntarily without being coerced; my child may refuse to participate in this study or in any part of this study, and I may withdraw my consent at any time, without prejudice to my relations or my child's with SJSU or the individual high school involved.

HAVING READ THE INFORMATION PROVIDED ABOVE, I HAVE MADE A DECISION WHETHER OR NOT MY CHILD MAY PARTICIPATE. MY SIGNATURE INDICATES THAT MY CHILD MAY PARTICIPATE AND IS WILLING TO PARTICIPATE.

$\overline{\text { DATE }} \overline{\text { PARENT/GUARDIAN SIGNATURE }} \overline{\text { PRINT CHILD'S NAME }}$ 


\section{APPENDIX L STATEMENT READ TO SUBJECTS}

\section{DIRECTIONS TO SUBJECTS}

Hello. My name is Mary Brkich. I am a graduate student in Athletic Training at San Jose State University, and a certified athletic trainer. I am conducting a study of "Prevalence of Ergogenic Aid Use among Female High School Athletes." Ergogenic aids are substances thought to enhance athletic performance. Most studies of this type deal with male athletes, and I thought it was important to address the female athletic population as well. I believe you have special needs that should be researched also.

The purpose of this study is to get an idea of what substances you might use to help you improve your athletic performance, how often you use them, for which sports, and why you use them. Your opinion about performanceenhancing drug use is also included in the questionnaire.

This questionnaire is completely optional. You do not have to fill it out. However, your consent is implied by filling it out. Do not put your name on it. It is completely anonymous. I will be the only one to see your responses. Teachers and coaches will be given aggregate data only and no individual school data can be identified. Ensuring your anonymity is very important to me, and is important to the success of this project.

The questionnaire will take about 5-10 minutes to complete. When you finish, please place it in the box at the front of the room. Thank you for your help and cooperation. 